\title{
Pengaruh Pemberian Ekstrak Rosella (Hibiscus sabdariffa Linn) Terhadap Kadar Malondialdehid dan Aktivitas Katalase Tikus yang Terpapar Karbon Tetraklorida
}

\author{
Zuraida $^{1}$, Eti Yerizel², Eliza Anas $^{3}$
}

Abstrak

Pemberian rosella (Hibiscus sabdariffa Linn) diharapkan melindung hepar tikus dari kerusakkan akibat stres oksidatif pada keracunan karbon tetraklorida $\left(\mathrm{CCl}_{4}\right)$. Senyawa yang sering dijadikan petunjuk adanya kerusakan tersebut adalah malondialdehid (MDA). Rosella mengandung vitamin C, flavonoid, polifenol dan beta karoten. Tujuan penelitian ini adalah menentukan pengaruh pemberian ekstrak rosella (Hibiscus sabdariffa Linn) terhadap MDA dan aktivitas katalase tikus yang terpapar $\mathrm{CCl}_{4}$. Ini adalah penelitian eksperimental dengan desain Post test Only Control Group Design. Sampel 24 ekor tikus Strain Wistar berumur 2-3 bulan, berat 150-200 gr. Sampel diambil secara acak dan dibagi 4 kelompok terdiri dari kelompok kontrol negatif, kontrol positif $\left(\mathrm{CCl}_{4}\right)$, perlakuan $1\left(\mathrm{CCl}_{4}\right.$ dan ekstrak rosella $250 \mathrm{mg} / \mathrm{kg} \mathrm{bb}$ ) dan perlakuan 2 ( $\mathrm{CCl}_{4}$ dan ekstrak rosella $\left.500 \mathrm{mg} / \mathrm{kg} \mathrm{bb}\right)$. Pemberian $\mathrm{CCl}_{4}$ secara oral dosis tunggal, setelah 24 jam kemudian diberi ekstrak rosella secara oral selama 14 hari. Data dianalisis dengan uji Anova, tingkat kepercayaan 95\%.Pemberian ekstrak rosella secara statistik didapatkan perbedaan yang signifikan rerata kadar MDA dan katalase antar kelompok $(p<0,05)$. Disimpulkan bahwa ekstrak rosella dapat menurunkan kadar MDA dan meningkatkan aktivitas katalase tikus yang terpapar $\mathrm{CCl}_{4}$.

Kata kunci: karbon tetraklorida, MDA, katalase, rosella

\section{Abstract}

Administering roselle (Hibiscus sabdariffa Linn) is expected to protect rat liver from damage caused by oxidative stress in CCl4 poisoning. Rosella contains vitamin C, flavonoids, polyphenol and beta carotene. Compounds which was often used as marker of the damage caused by free radicals wa MDA. The objective of this study was to determine the effect of extracts of roselle (Hibiscus sabdariffa Linn) on MDA and catalase activity of rats exposed to CCl4. Experimental research design with Post test Only Control Group Design. Samples of 24 male Wistar Strain rats were 2-3 months old. weighing 150-200 gr. Samples were taken at random and divided into 4 groups consisting of a negative control group, positive control (CCl4), treatment 1 (CCl4 and roselle extract $250 \mathrm{mg} / \mathrm{kg}$ bw) and treatment 2 (CCl4 and roselle extract $500 \mathrm{mg} / \mathrm{kg} \mathrm{bw).} \mathrm{CCl4} \mathrm{was} \mathrm{given} \mathrm{a} \mathrm{single} \mathrm{dose} \mathrm{orally,} \mathrm{after} 24$ hours, the subjects were given rosella extract orally for 14 days. Data were analyzed by ANOVA with a confidence level of 95\%. Rosella extract obtained statistically significant differences of MDA and catalase levels among groups $(p<0.05)$. It can be concluded that the rosella extract can reduce levels of MDA and increase the activity of catalase mice exposed to CCl4. From the research it can be concluded that the rosella extract can reduce levels of MDA and increas the activity of catalase mice exposed to $\mathrm{CCl}_{4}$. It is needed further research on the toxicity of extracts of rosella and organ damage caused.

Keywords: carbon tetrachloride, MDA, catalase, rosella 
Affiliasi penulis: 1. Program Studi Magister Biomedik FK UNAND (Fakultas Kedokteran Universitas Andalas Padang), 2. Bagian Biokimia FK UNAND, 3. Bagian Biologi FK UNAND.

Korespondensi: Zuraida, E-mail: zuraida_jauza@yahoo.com, Telp: 081374694580

\section{PENDAHULUAN}

Radikal bebas berperan dalam terjadinya berbagai penyakit degeneratif, karena radikal bebas memiliki lektron yang tidak berpasangan pada orbit terluarnya, sehingga bersifat reaktif untuk bereaksi dengan molekul lain. Radikal bebas dapat merusak makromolekul seperti merusak lipid membran sel, DNA, protein yang menyebabkan stress oksidatif sel. ${ }^{1}$

Dalam keadaan normal, produk radikal bebas tidak akan menyebabkan kerusakan hepar, karena dibandingkan organ lain, hepar memiliki sistem protektor antioksidan yang terbaik. ${ }^{2}$ Dalam beberapa keadaan, dimana terdapat peningkatan radikal bebas yang disebabkan oleh pemicu, maka dapat terjadi dampak negatif pada sel hepar. ${ }^{3}$ Beberapa obat dan bahan kimia yang telah dikenal dapat meningkatkan radikal bebas adalah karbon tetraklorida $\left(\mathrm{CCL}_{4}\right)$ dan haloten. ${ }^{4}$

Salah satu zat kimia yang bersifat oksidan dan dapat merusak hepar (hepatotoksik) adalah $\mathrm{CCl}_{4}$. Pada Penelitian ini, $\mathrm{CCl}_{4}$ digunakan sebagai induktor kerusakan hati.

Karbon tetraklorida akan dimetabolisme di reticulum endoplasma pada sel hati. $\mathrm{CCL}_{4}$ dimetabolisme oleh sitokrom P450 menghasilkan zat yang reaktif yaitu radikal $\mathrm{CCL}_{3}{ }^{\circ}$. Radikal bebas $\mathrm{CCL}_{3}{ }^{\circ}$ akan segera bereaksi dengan oksigen membentuk radikal $\mathrm{CCl}_{3} \mathrm{O}_{2}$ yang jauh lebih reaktif dari pada $\mathrm{CCl}_{3}{ }^{\circ}$. Sifat $\mathrm{CCl}_{3} \mathrm{O}_{2}$ sangat reaktif terhadap biomolekul seperti protein, lipid, karbohidrat dan nukleotida. Akibatnya fungsi biologis biomolekuler akan terganggu dan akhirnya menyebabkan kematian sel. Triklorometilperoksida menyebabkan inisiasi lipid peroksidase oleh $\mathrm{H}^{*}$. Peningkatan $\mathrm{Ca}^{2+}$ intraseluler meningkatkan kerusakan protein, DNA dan aktivasi phospholipase. Meningkatnya kadar lipid peroksidasi darah dan hepar yang ditandai dengan meningkatnya kadar MDA hepar dan plasma sebagai hasil akhir degradasi lipid peroksida. ${ }^{5}$

Malondialdehid merupakan salah satu senyawa yang dapat menggambarkan aktivitas oksidan (radikal bebas) dalam sel, sedangkan glutation dan katalase menggambarkan aktivitas antioksidan dalam sel.
Senyawa yang sering dijadikan petunjuk adanya kerusakan akibat radikal bebas adalah MDA, glutation (GSH) dan enzim katalase. ${ }^{6}$

Salah satu antioksidan endogen adalah enzim katalase. Aktivitas enzim katalase akan meningkat apabila radikal bebas meningkat. Apabila jumlah radikal bebas tidak seimbang dengan kemampuan antioksidan untuk meredamnya, maka aktivitas akan berkurang. Enzim katalase termasuk enzim hidroperoksidase yang melindungi tubuh terhadap senyawa peroksida yang berbahaya. Penumpukan senyawa peroksida dapat menghasilkan radikal bebas, yang selanjutnya akan merusak membran sel dan kemungkinan dapat menimbulkan penyakit kanker serta arterosklerosis yang memiliki kemampuan untuk inaktivasi hidrogen peroksida. Senyawa $\mathrm{H}_{2} \mathrm{O}_{2}$ dihasilkan oleh aktivitas enzim oksidase, $\mathrm{H}_{2} \mathrm{O}_{2}$ berpotensi menimbulkan efek radikal bebas karena membentuk $\mathrm{OH}^{*}{ }^{7}$

Untuk meredam efek radikal bebas terhadap kerusakan hepar diperlukan suatu antioksidan. Diketahui banyak sekali sumber antioksidan, antioksidan dibedakan dua kelompok; 1. Antioksidan enzimatis yang termasuk di dalamnya adalah enzim superoksida dismutase (SOD), katalase, glutation peroksidase (GSH-px), serta glutation reduktase (GSH) yang dapat memberikan atom hidrogen secara cepat kepada senyawa radikal, kemudian radikal oksidan yang terbentuk segera berubah menjadi senyawa yang lebih stabil. ${ }^{8}$ 2. Antioksidan non enzamatis (Eksogen): vitamin C, betakaroten, vitamin E, flavonoid dan senyawa fenolik. ${ }^{9}$

Rosella merupakan salah satu antioksidan eksogen alami. Rosella saat ini populer, karena hampir seluruh bagian tanaman ini dapat digunakan untuk kebutuhan pengobatan. Rosela juga memiliki kandungan senyawa kimia yang dapat memberikan banyak manfaat. ${ }^{10}$ Rosela mengandung pigmen antosianin yang dapat berfungsi sebagai antioksidan, karena antosianin merupakan senyawa yang dapat menjaga fungsi hati akibat radikal bebas. Sebagai antioksidan rosela juga mengandung metanol, asam askorbat, $\beta$-karoten dan asam protokatekuat. Kandungan metanol dan polifenol pada rosela juga berperan sebagai anti inflamasi yang mencegah kerusakan sel bartambah parah. ${ }^{11}$ Rosella juga mengandung : vitamin $\mathrm{C}$, flavonoid, polifenol dan beta karoten. ${ }^{12}$ 
Kandungan kelopak bunga rosella segar dalam 100 gram yaitu air 9,2 gr, protein 1,145 gr, lemak 2,61 gr, serat $12.0 \mathrm{gr}$, abu 6,90 gr, kalsium 1,263 ge, fosforus $273,2 \mathrm{mg}$, zat besi $8,89 \mathrm{gr}$, karoten $0,029 \mathrm{mg}$, thiamin $0,117 \mathrm{mg}$, riboflavin, $0,277 \mathrm{mg}$, niacin $3,765 \mathrm{mg}$, asam askorbat 6,7 mg. Rosella juga mengandung vitamin B1, B2, niasin dan vitamin D serta mengandung 18 asam amino. Kadar antioksidan yang tinggi pada kelopak rosela dapat menghambat radikal bebas. ${ }^{13}$

Penelitian yang dilakukan oleh Dahiru et al di tahun 2003, tentang efek ekstrak rosela terhadap kerusakan hati akibat $\mathrm{CCL}_{4}$ menunjukkan bahwa pemberian ekstrak rosela 250 dan $500 \mathrm{mg} / \mathrm{kg}$ berat badan dapat menurunkan kadar SGOT dan SGPT dan protein total pada hati, tetapi bagaimana efek ekstrak rosela dalam menurunkan toksisitas $\mathrm{CCl}_{4}$ melalui metabolisme MDA dan Katalase belum diketahui. ${ }^{14}$

Pada penelitian ini pemberian $\mathrm{CCl}_{4}$ pada tikus menyebabkan meningkatnya radikal bebas, maka penggunaan rosella tujuannya sebagai peredam efek radikal bebas akibat $\mathrm{CCl}_{4}$. Dengan pemberian antioksidan rosella diharapkan dapat melindung hati tikus dari kerusakkan akibat stres oksidatif pada keracunan $\mathrm{CCl}_{4}$. Setelah pemberian rosella diharapkan lipid peroksidasi menurun sehingga kadar MDA menurun dan katalase meningkat.

Berdasarkan latar belakang diatas maka perlu dilakukan suatu penelitian pengaruh pemberian ekstrak rosella (Hibiscus sabdariffa Linn) terhadap kadar MDA dan aktivitas katalase tikus yang terpapar $\mathrm{CCl}_{4}$.

\section{METODE}

Penelitian ini dilaksanakan secara experimental dengan desain post test only control group design yaitu rancangan yang digunakan untuk mengukur pengaruh perlakuan pada kelompok eksperimen dengan cara membandingkan perlakuan dengan kelompok kontrol pada saat sesudah perlakuan. ${ }^{15}$

Dalam penelitian ini digunakan enam ekor untuk setiap kelompok. Jumlah tersebut memenuhi ketetapan WHO, yaitu setiap kelompok minimal terdiri dari 5 ekor tikus. ${ }^{16}$ Sampel dibagi menjadi empat kelompok, yaitu kelompok kontrol negatif, kelompok kontrol positif, kelompok perlakuan 1 dan kelompok perlakuan 2.

\section{Pemilihan dan Pemeliharaan Hewan Uji}

Tikus yang dijadikan sampel adalah tikus jantan Wistar, berumur 2-3 bulan, dengan berat badan antara 150-200 gram. Tikus yang berasal dari Unit Pengembangan Hewan Penelitian (UHPH) Surabaya Penyesuaian lingkungan atau adaptasi selama 1 minggu sebelum diberi perlakuan. Tikus tersebut dipelihara dalam kandang plastik dengan anyaman kawat sebagai penutup. Kandang ditempatkan dalam ruangan yang memiliki ventilasi dan mendapat cahaya matahari langsung. Kandang, tempat makanan dan minuman dibersihkan tiga kali dalam seminggu. Temperature dipertahankan pada suhu kamar, kelembaban antara 40-60\%. Pemberian makan dan minum dilakukan setiap hari secara ad libitum. Pakan yang diberikan berupa pellet C-05 produksi PT. Charoen Medan dan aquades. Jumlah konsumsi pakan perhari rata - rata $5 \mathrm{gr} / 100 \mathrm{grbb} .{ }^{17}$

Sebelum perlakuan, terlebih dahulu dilakukan penimbangan berat badan tikus. Tikus yang sudah ditimbang dimasukkan ke dalam kandang yang masingmasing kandang berisi 8 ekor tikus.

\section{Pembuatan ekstrak rosella}

Penyiapan simplisia kelopak bunga rosella diperoleh dari hasil budidaya para petani di Solok Selatan. Kelopak bunga rosella yang telah diambil dibersihkan dari semua kotoran yang melekat lalu dicuci sampai bersih. Selanjutnya dikeringkan dengan cara diangin-anginkan di udara terbuka dan terlindung dari cahaya matahari. Kemudian diserbuk dan diayak dengan pengayak nomor 40 sehingga diperoleh serbuk yang homogen. Serbuk simplisia kering yang sebelumnya sudah diayak dengan menggunakan pengayak nomor 40, dimasukkan ke dalam wadah maserasi.

Maserasi dimulai dengan cara menuangkan etanol $70 \%$ ke dalam wadah maserasi (botol yang berwarna gelap) sampai seluruh simplisia terendam dan pelarut dilebihkan setinggi kurang lebih $2 \mathrm{~cm}$ di atas permukaan simplisia. Simplisia direndam selama 3 hari, selama perendaman dilakukan pengadukan 2 kali sehari agar senyawa yang terdapat pada kelopak bunga rosella dapat larut dengan baik. Maserat dipisahkan dan proses diulangi dua kali dengan jumlah pelarut yang sama. Maserat yang diperoleh dikumpulkan dan 
dipekatkan dengan rotary evaporator pada suhu dibawah $60^{\circ} \mathrm{C}$ sehingga diperoleh ekstrak kental.

\section{Pemberian Karbontetraklorida $\left(\mathrm{CCl}_{4}\right)$}

a. Pemberian karbon tetraklorida dilakukan sebanyak 1 kali (dosis tunggal).

b. Pengenceran $1 \mathrm{ml} \mathrm{CCl}_{4}$ dilarutkan menjadi $5 \mathrm{ml}$ dengan pelarut minyak jagung, jadi volume pemberian $1 \mathrm{cc} / 200$ gram.

c. Posisi tikus dipegang sedemikian rupa, diberikan secara oral yaitu dimasukkan melalui tepi langitlangit sambil didorong perlahan-lahan kebelakang sampai oesephagus.

d. Dosis $\mathrm{CCl}_{4}$ yang diberikan sebanyak $1 \mathrm{ml} / \mathrm{kgbb}$.

\section{Pemberian dosis ekstrak rosella}

Dosis ekstrak kelopak bunga rosella yang digunakan pada penelitian ini adalah 250 dan 500 $\mathrm{mg} / \mathrm{kg}$ BB tikus.

\section{Perlakuan pada Hewan Coba}

Sebelum dilakukan intervensi, tikus dipilih secara acak dan dibagi menjadi 4 kelompok, yaitu:

1. Kelompok 1 Kontrol Negatif (KN) kontrol negatif (tanpa paparan $\mathrm{CCL}_{4}$ )

2. Kelompok 2 Kontrol Positif (KP) diberikan $\mathrm{CCL}_{4} 1,0$ $\mathrm{ml} / \mathrm{kgbb}$ dosis tunggal.

3. Kelompok 3 Perlakuan (P1) diberikan $\mathrm{CCL}_{4}$ 1,0 $\mathrm{ml} / \mathrm{kgbb}$ dosis tunggal, 24 jam kemudian di beri ekstrak rosela $250 \mathrm{mg} / \mathrm{kgbb}$ selama 14 hari.

4. Kelompok 4 Perlakuan (P2) diberikan CCL4 1,0 $\mathrm{ml} / \mathrm{kgbb}$ dosis tunggal, 24 jam kemudian di beri ekstrak rosela $500 \mathrm{mg} / \mathrm{kgbb}$ selama 14 hari.

Pemeriksaaan kadar MDA dengan spektrofotometer dan pemeriksaan katalase dengan menggunakan Metode Sinha menggunakan zat warna sebagai indikator.

Hasil penelitian dilakukan tabulasi data dan dianalisa dengan menggunakan uji ANOVA dengan derajat kepercayaan 95\%. Jika didapatkan hasil yang bermakna dilanjutkan dengan uji statistik Multiple Comparisons (Post Hoc Test) jenis Bonferroni. ${ }^{18}$
HASIL

KADAR MALONDIALDEHID (MDA)

Tabel 1. Pengaruh Pemberian ekstrak rosella terhadap kadar MDA tikus yang terpapar karbon tetraklorida

\begin{tabular}{|c|c|c|c|}
\hline No & Kelompok & Kadar MDA (nmol/ml) & \multirow{2}{*}{ p } \\
\hline & & Rerata \pm SD & \\
\hline 1 & $\mathrm{KN}$ & $2,47 \pm 0,24$ & \multirow{4}{*}{0,0005} \\
\hline 2 & $\mathrm{KP}$ & $4,70 \pm 1,39$ & \\
\hline 3 & P1 & $4,29 \pm 0,32$ & \\
\hline 4 & P2 & $3,25 \pm 0,30$ & \\
\hline
\end{tabular}

Berdasarkan Tabel 1 dapat dilihat bahwa pada kelompok Kontrol Positif terjadi peningkatan kadar MDA dibandingkan kelompok Kontrol Negatif. Sedangkan pada kedua kelompok perlakuan pemberian ekstrak rosella (Kelompok P1 dan P2) terjadi penurunan kadar MDA. Penurunan kadar MDA yang mendekati Kontrol Negatif adalah pada Kelompok Perlakuan 2. Penelitian ini menunjukan ekstrak rosella memiliki pengaruh sebagai antioksidan dengan menurunkan kadar MDA pada tikus yang diinduksi $\mathrm{CCl}_{4}$.

Pada uji ANOVA, didapatkan $\mathrm{p}=0,0005$ $(p<0,05)$. Secara statistik perbedaan tersebut bermakna, yang berarti ada pengaruh pemberian ekstrak rosella sebagai antioksidan terhadap penurunan kadar MDA pada tikus. Untuk melihat perbedaan antara kelompok maka dilanjutkan dengan uji Post Hoc Test Multiple Comparisons, jenis Bonferroni hasilnya dapat dilihat pada Tabel 2.

Tabel 2. Hasil uji post hoc test kadar MDA (nmol/ml) pada masing-masing kelompok penelitian

\begin{tabular}{cccccc}
\hline No & Kelompok & KN & KP & P1 & P2 \\
\hline 1 & KN & - & - & - & - \\
2 & KP & $0,000^{*}$ & - & - & - \\
3 & P1 & $0,002^{*}$ & 1,000 & - & - \\
4 & P2 & 0,503 & $0,017^{*}$ & 0,145 & -
\end{tabular}

Ket: * terdapat perbedaan bermakna

Berdasarkan Tabel 2 terlihat bahwa adanya perbedaan yang signifikan $(p<0,05)$ rerata MDA antara kelompok kontrol negatif dengan kelompok kontrol positif, antara kelompok kontrol negatif dengan kelompok perlakuan 1 dan antara kelompok kontrol 
positif dengan kelompok perlakuan 2. Rerata kadar MDA pada kelompok kontol negatif dengan perlakuan 2, antara kelompok kontrol positif dengan perlakuan 1 dan antara perlakuan 1 dan perlakuan 2 tidak ada perbedaan yang signifikan $(p<0,05)$. Dapat disimpulkan bahwa dosis ekstrak rosella $500 \mathrm{mg} / \mathrm{kgbb}$ berbeda signifikan $(p<0,05)$ dibandingkan pemberian dosis ekstrak rosella $250 \mathrm{mg} / \mathrm{kgbb}$.

\section{Aktivitas Katalase}

Tabel 3. Pengaruh pemberian ekstrak rosella terhadap aktifitas katalase tikus yang terpapar karbon tetraklorida.

\begin{tabular}{cccc}
\hline No & Kelompok & Katalase (unit/mg) & P \\
\cline { 1 - 3 } & & Rerata \pm SD & \\
\hline 1 & KN & $1,48+0,09$ & \\
2 & KP & $1,08+0,02$ & 0,0005 \\
3 & P1 & $1,21+0,01$ & \\
4 & P2 & $1,39+0,03$ & \\
\hline
\end{tabular}

Berdasarkan Tabel 3 dapat dilihat terjadi terjadi penurunan rerata kadar Katalase pada kelompok Kontrol Positif yang diberikan $\mathrm{CCL}_{4} 1 \mathrm{ml} / \mathrm{Kg} \quad \mathrm{BB}$ dibandingkan Kelompok Kontrol Negatif. Pada kedua kelompok perlakuan pemberian ekstrak rosella (P1 dan P2) terjadi peningkatan aktivitas Katalase dibandingkan dengan Kelompok Kontrol Positif terutama pada Kelompok Perlakuan 2. Penelitian ini menunjukan ekstrak rosella memiliki pengaruh sebagai antioksidan dengan meningkatnya aktivitas katalase pada kelompok pemberian ekstrak rosella.

Pada uji ANOVA, didapatkan $\mathrm{p}=0,0005$ $(p<0,05)$, Secara statistik perbedaan tersebut bermakna, yang berarti ada pengaruh pemberian ekstrak rosella sebagai antioksidan terhadap peningkatan aktifitas katalase pada tikus yang terpapar CCL4. Untuk melihat perbedaan antara kelompok maka dilanjutkan dengan uji Post Hoc Test Multiple Comparisons, jenis Bonferroni yang hasilnya dapat dilihat pada pada Tabel 4.

Tabel 4. Hasil uji post hoc test katalase (unit/mg) pada masing masing kelompok penelitian

\begin{tabular}{cccccc}
\hline No & Kelompok & KN & KP & P1 & P2 \\
\hline 1 & KN & - & - & - & - \\
2 & KP & $0,000^{*}$ & - & - & - \\
3 & P1 & $0,000^{*}$ & $0,001^{*}$ & - & - \\
4 & P2 & $0,016^{*}$ & $0,000^{*}$ & $0,000^{*}$ & - \\
\hline
\end{tabular}

ket: * terdapat perbedaan bermakna
Berdasarkan Tabel 4, terlihat bahwa adanya perbedaan yang signifikan $(p<0,05)$ rerata katalase antara kelompok kontrol negatif dengan kelompok kontrol positif, perlakuan 1 dan perlakuan 2, antara kontrol positif dengan perlakuan 1 dan 2 serta antara perlakuan I dengan kelompok perlakuan II. Dapat disimpulkan bahwa dengan pemberian dosis ekstrak $250 \mathrm{mg} / \mathrm{kgbb}$ sudah terjadi peningkatan aktifitas katalase secara signifikan $(p<0,05)$ dan dengan peningkatan dosis $500 \mathrm{mg} / \mathrm{kgbb}$ terlihat perbedaan yang lebih signifikan $(p<0,05)$

\section{PEMBAHASAN}

\section{Pengaruh Pemberian Ekstrak Rosella (Hibiscus sabdariffa Linn) Terhadap kadar MDA Tikus Yang Terpapar Karbon Tetraklorida.}

Berdasarkan Tabel 1 dapat dilihat terjadi peningkatan rerata kadar MDA pada kelompok kontol positif yang diberi $\mathrm{CCl}_{4}$, peningkatan kadar MDA ini berarti bahwa $\mathrm{CCl}_{4}$ memang bersifat hepatotoksik yang bekerja melalui metabolik reaktifnya yaitu $\mathrm{CCl}_{3}{ }^{*}$ yang mengikat protein dan lipid tidak jenuh pada membran sel sehingga menyebabkan terjadinya peroksida lipid yang akhirnya akan membentuk MDA. Penimbunan peroksida lipid inilah yang akan merusak membran sel sehingga mengganggu fungsi dan struktur sel. Jumlah radikal bebas yang berlebih mengakibatkan peningkatan proses peroksidasi lipid sehingga produksi MDA juga meningkat. Patofisiologi $\mathrm{CCl}_{4}$ dalam metabolisme tubuh menghasilkan senyawa radikal bebas $\mathrm{CCl}_{3}$ dan $\mathrm{CCl}_{3} \mathrm{O}_{2}$ yang menyebabkan terjadinya peroksidasi lipid, sedangkan MDA merupakan produk akhir peroksidasi lipid sehingga pemberian $\mathrm{CCl}_{4}$ berbanding lurus dengan peningkatan kadar MDA di dalam darah. Oleh karena itu, kelompok tikus yang diberi $\mathrm{CCl}_{4}$ mengalami peningkatan kadar MDA. ${ }^{19}$

Pada kelompok perlakuan 1 yang diberi ekstrak rosella $250 \mathrm{mg} / \mathrm{kg}$ bb terjadi penurunan kadar MDA dibandingkan dengan kelompok kontrol positif. Hal ini menunjukkan bahwa pemberian ekstrak rosella 250 $\mathrm{mg} / \mathrm{kgbb}$ pada tikus yang terpapar $\mathrm{CCl}_{4}$ dapat menurunkan kadar MDA darah secara signifikan. Penurunan kadar MDA darah pada kelompok perlakuan diatas disebabkan pengaruh ekstrak rosella yang berfungsi sebagai antioksidan, yaitu asam organik, asam malat, asam oksalat, vitamin A, B, C serta 
senyawa polifenol dan flavonoid yang mempunyai fungsi sebagai antioksidan sehingga radikal ini tidak akan merusak sel dan lipid tidak mengalami peroksidasi sehingga reaksi rantai pembentukan MDA tidak terjadi. Menurut Soewoto di tahun 2001 dan Lampe di tahun 1999, antioksidan non-enxzimatik meliputi vitamin C, flavonoid yang kerja sistem antioksidan ini dengan cara memotong reaksi oksidasi berantai dari radikal bebas atau dengan cara menangkapnya. Akibatnya, radikal bebas tidak akan bereaksi dengan komponen seluler. ${ }^{20,21}$

Pada kelompok perlakuan 2 yang diberi ekstrak rosella $500 \mathrm{mg} / \mathrm{kg}$ bb terjadi penurunan kadar MDA dibandingkan dengan kelompok kontrol positif dan perlakuan I. Hal ini menunjukkan bahwa pemberian ekstrak rosella $500 \mathrm{mg} / \mathrm{kg}$ bb pada tikus yang terpapar $\mathrm{CCl}_{4}$ dapat menurunkan kadar MDA darah secara signifikan. Penurunan kadar MDA darah pada kelompok perlakuan diatas disebabkan pengaruh ekstrak rosella yang berfungsi sebagai antioksidan. Hasil penelitian ini sesuai dengan beberapa studi yang telah dilakukan, yang menyebutkan bahwa rosella mengandung antioksidan diantaranya: vitamin $\mathrm{C}$, beta karoten dan omega $3 .^{22,23}$

Pada penelitian ini didapatkan, efek menurunkan kadar MDA lebih besar pada pemberian ekstrak rosella dengan dosis yang lebih tinggi (500 mg/kgbb). Hal ini mungkin disebabkan makin tinggi pemberian dosis ekstrak rosella akan menyebabkan makin tinggi pula antioksidan yang dikonsumsi, sehingga makin kuat pula meredam peroksidasi lipid yang ditimbulkan radikal bebas. Hasil penelitian ini didukung oleh penelitian yang dilakukan Dahiru et al di tahun 2003. ${ }^{14}$

Rosella (Hibiscus sabdariffa Linn) mengandung senyawa antioksidan yaitu asam askorbat yang berfungsi sebagai donor elektron sehingga dapat berikatan dengan metabolit triklorometil. Dengan demikian, radikal triklorometil tidak akan merusak sel dan menyebabkan peroksidasi lipid tidak berjalan, reaksi rantai tidak terjadi, kebocoran membran yang berakibat meningkatnya kadar MDA serum tidak terjadi, dan nekrosis sentrilobuler tidak terjadi.

Vitamin $C$ atau $L$-ascorbic acid yang dikandung ekstrak rosella merupakan senyawa hidrofilik. Senyawa ini merupakan antioksidan yang penting dalam cairan ekstraseluluer. Vitamin C secara efesien dapat mencegah terbentuknya superoksida, hydrogen peroksida, hipoklirit, radikal hidrosil, radikal peroksil dan radikal oksigen. Vitamin C lebih efektif dalam menghambat peroksidasi lemak oleh radikal peroksil bila dibandingkan komponen plasma lain seperti $\alpha$ tokoferol. Vitamin C dapat mencegah peroksidasi membrane dengan meningkatkan aktifitas tokoferol dan mencegah kerusakan sel akibat radikal oksigen. ${ }^{24}$

Betakaroten yang terkandung dalam rosella juga dapat berfungsi sebagai penangkal radikal bebas karena peran antioksidannya. Radikal bebas merupakan senyawa yg dapat merusak sel, bahkan dapat memicu timbulnya kelainan minimal pada tingkat sel yang selanjutnya berubah menjadi pre-kanker. Betakaroten memberikan perlindungan pada tingkat seluler dimana DNA (deoxyribonucleic acid) yang merupakan suatu inti genetik pembawa sifat keturunan diproteksi terhadap berbagai gangguan sehingga dapat terlindung dari 'bahan asing' yang mengacaukan kode genetiknya. Betakaroten juga memiliki kemampuan untuk memproteksi sel normal dari sel mutan (yang telah mengalami perubahan) pemicu pertumbuhan kanker. Betakaraten berperan sebagai donor elektron dan dapat mencegah keadaan stess oksidatif. Aktivitas antioksidan karotenoid terdapat pada kemampuannya untuk member elektron dari struktur ikatan rangkapnya. Elektron yang dilepaskan akan berikatan dengan elektron yang belum berpasangan dari radikal bebas. ${ }^{5}$

Kegunaan flavonoid dapat mencegah jejas akibat radikal bebas dalam beberapa cara. Salah satunya dengan membersihkan radikal secara langsung. Flavonoid akan teroksidasi oleh radikal sehingga menjadikan radikal lebih stabil dan kurang reaktif. Dengan kata lain flavonoid menstabilkan ROS dan bereaksi dengan senyawa radikal yang reaktif. ${ }^{25}$ Polifenol dan flavonoid telah diketahui memiliki aktifitas antioksidan, antiinflamasi, hepatoprotektif, antitrombosis, antiviral dan antikarsinogen. ${ }^{26}$ Salah satu penelitian tentang kapasitas antioksidan pada spesies cucumaria frondoso, kandungan polifenol total pada berbagai sistem organ bervariasi dari 22,5 sampai 236,0 $\mathrm{mg} / 100$ gram berat kotor, dan flavonoid total dari 2,9 sampai 59,8/100 gram. Kapasitas absorban radikal oksigen atau kapasitas antioksidan mulai dari 140 sampai $800 \mu \mathrm{mol} / g r a m$ berat kotor. ${ }^{27}$

Penelitian ini didukung oleh penelitian yang dilakukan Suweino et al menemukan bahwa pemberian sari buah mengkudu pada tikus yang dipapari $\mathrm{CCl}_{4}$ 
dapat menurunkan kadar MDA plasma dan MDA hati tikus dibanding kelompok yang dipapari $\mathrm{CCl}_{4}$ tanpa diberi sari buah mengkudu. ${ }^{28}$

\section{Pengaruh Pemberian Ekstrak Rosella (Hibiscus sabdariffa Linn) Terhadap Aktivitas Katalase Tikus Yang Terpapar Karbon Tetraklorida}

Berdasarkan Tabel 3 dapat dilihat terjadi penurunan rerata kadar katalase pada kelompok kontol positif yang diberi $\mathrm{CCl}_{4}$, penurunan kadar Katalase ini berarti bahwa metabolit dari $\mathrm{CCl}_{4}$, yaitu $\mathrm{CCl}_{3}$ dan $\mathrm{CCL}_{3} \mathrm{O}_{2}$ akan menyebabkan kerusakan hati secara struktural maupun fungsional. ${ }^{29}$ Tikus yang terpapar $\mathrm{CCl}_{4}$ didalam tubuhnya, kemudian $\mathrm{CCl}_{4}$ akan dimetabolisme diretikulum endoplasma pada sel hati, hasil metabolismenya bersifat radikal bebas. Senyawa radikal bebas tersebut adalah $\mathrm{CCl}_{3}$ dan $\mathrm{CCl}_{3} \mathrm{O}_{2}$. Radikal bebas ini menyerang komponen lipid membran sel hati sehingga menyebabkan kerusakan/kematian sel. Reaksi oksidasi tidak hanya menyerang komponen lipid, melainkan komponen sel lainnya seperti protein, lipoprotein maupun DNA. Pada saat produksi radikal bebas maka aktifitas katalase akan mengalami penurunan karena $\mathrm{H}_{2} \mathrm{O}_{2}$ akan menjadi ${ }^{*} \mathrm{OH}$ (Radikal Hidroksil) yang sangat toksik ini bisa merusak protein, membran sel dan DNA. ${ }^{19}$

Pada kelompok perlakuan 1 yang diberi ekstrak rosella $250 \mathrm{mg} / \mathrm{kg}$ bb terjadi peningkatan katalase dibandingkan dengan kelompok kontrol positif. Hal ini menunjukkan bahwa pemberian ekstrak rosella 250 $\mathrm{mg} / \mathrm{kg}$ bb pada tikus yang terpapar $\mathrm{CCl}_{4}$ dapat meningkatkan katalase darah secara signifikan.

Pada kelompok perlakuan 2 yang diberi ekstrak rosella $500 \mathrm{mg} / \mathrm{kg}$ bb terjadi peningkatan katalase dibandingkan dengan kelompok kontrol positif dan perlakuan 1. Hal ini menunjukkan bahwa dengan pemberian ekstrak rosella sebagai antioksidan dapat meredam efek radikal bebas yang ditimbulkan oleh $\mathrm{CCl}_{4}$. Vitamin $\mathrm{C}$, polivenol, flavonoid dan beta karoten yang terkandung dalam rosella akan meningkatkan aktifitas katalase. Peningkatan katalase akan menyebabkan penguraian $\mathrm{H}_{2} \mathrm{O}_{2}$ menjadi $\mathrm{H}_{2} \mathrm{O}$ dan $\mathrm{O}_{2}$ yang tidak toksik.

Pemberian ekstrak rosella dengan dua dosis diatas didapatkan bahwa terjadi peningkatan katalase setelah diberikan ekstrak rosella adalah pada kelompok perlakuan 2. Hal ini sama halnya dengan kadar MDA juga didapatkan pada kelompok perlakuan 2 sebagai dosis optimal.

Penelitian ini didukung oleh Adam et al tahun 2013, yang telah melakukan penelitian Pengaruh Pemberian Ekstrak Biji Jengkol (Archidendron pauciforum) pada aktivitas spesifik katalase jaringan hati tikus yang diintoksikasi Karbon Tetraklorida dan hasil penelitian memperlihatkan bahwa terjadi peningkatan aktivitas spesifik katalase setelah diberikan ekstrak biji jengkol. ${ }^{30}$

\section{UCAPAN TERIMA KASIH}

Terima kasih kepada staf di laboratorium Biokimia Fakultas Kedokteran Universitas Andalas Padang

\section{DAFTAR PUSTAKA}

1. Valko M, Rhodes CJ, Moncol J, Izakovic M, Mazur M. Free radical, metal and antioxidant in oxidative stress induced cancer. J. Chem-Biol, Rusia. 2006;160(1).

2. Ali S. Peran radikal bebas pada patogenesa kerusakan hepar. Kumpulan Makalah, Seminar Dana Lokakarya Radikal Bebas Patogenesa Penyakit. Malang: Fakultas Kedokteran Universitas Brawijaya: 1997.

3. Cochrane GC. Celluler injuri by oxidants. Am.J.Med. 2004.

4. Feter JC, Somos G, Vereckel A. Role of free radical reaction in liver disease. Free radical and the liver, G.Csomos and J,Faher (eds). Springer Verlag. Berlin; 1992

5. Halliwell B, Gutteridge JMC. Free radicals in biology and medicine. Edisi ke-4 New York: Oxford University Press; 2007.

6. Enikarmila A. Malondialdehyde, reduced glutathione, and catalase activity of rat kidney tissue in chronic hypoxia. Jakarta: Majalah Kedokteran Indonesia. 2009; 59.

7. Wodpress. Enzim katalase. 2009 (diunduh April 2012). Tersedia dari: URL: HYPERLINK http://id.wodpress.org

8. Chevion S, Moran DS, Heled Y, Shani Y, Regrev,G, Abbou, et al. Plasma antioxidant status and cell injury after severe physical exercise. Proc Nati Acad Sci. 2003;100(9):5119-23. 
9. Kumalaningsih S. Antioksidan alami, Surabaya: Trubus Agrisarana; 2006.

10. Mardiah, Sawarni H, Ashadi RW, Rahayu A. Budi daya dan pengolahan rosela si merah segudang manfaat. Jakarta: Agromedia Pustaka; 2009.

11. Aspan R. Rosella (Hibiscus Sabdarifa Linn) serial data ilmiah terkini tumbuhan obat. Jakarta: Direktorat Obat Asli Indonesia. Badan Pengawas Obat dan makanan RI; 2010.

12. Pangkahila W. Memperlambat penuaan meningkatkan kualitas hidup. Anti- Aging Medicine. Jakarta. Penerbit Buku Kompas; 2007.

13. Rahmawati R. Budidaya rosella. Yogyakarta: Penerbit Pustaka Baru Press; 2012.

14. Dahiru D, Obi O, Umaru H. Effect of Hibiscus sabdariffa calyx extract on carbon tetrachloride induced liver damage. Biochemistry. 2003;15(1):2733.

15. Singarimbun M, Efendi S. Metode penelitian survei. Jakarta: LP3ES; 2006.

16. WHO. General guidelines for methodologies on research and evaluation of tradisional medicine. Geneva: WHO; 2000.

17. Kusumawati D. Bersahabat dengan hewan coba. Yogyakarta: Gajah Mada University Press; 2004.

18. Sudigdo S. Dasar - dasar metodologis penelitian klinis. Jakarta: Sagung Seto; 2011.

19. Suryohudoyo P. Kapita selekta ilmu kedokteran molekuler. Jakarta. Penerbit CV Sagung Seto; 2000.

20. Soewoto H. Antioksidan eksogen lini pertahanan kedua dalam menanggulangi peran radikal bebas. Dalam: Materi kursus penyegar radikal bebas dan antioksidan dalam kesehatan: dasar, aplikasi dan pemanfaatan bahan alam. Jakarta: FK-UI; 2001.

21. Lampe JW. Health effect of vegetables and fruit: assesing mechanism of action in human experimental studies. Dalam: The American Journal of Clinical Nutrition; 1999.

22. Arellano HA, Romero FS, Soto CMA, Tortoriello J.
Effectiveness and tolerability of a standardized extract from hibiscus sabdariffa in patients with mild to moderate hypertension, a controlled and Randomized Clinical Trial. Phytomedicine 11; 2004.

23. Maryani H, Kristiana L. Khasiat dan manfaat rosela. Jakarta. PT Agro Media Pustaka; 2008.

24. Sies $H$, Stahl W. Vitamin E and C, $\beta$-carotene, and caratenoids as antioxidants. AJCN. 1995. 62(suppl): 1315S-21S.

25. Kumar V, Fausto N.. Cellular adaptations, cell injury,and cell death. Dalam : Kumar V Abbas AK, Fausto $\mathrm{N}$, editor (penyunting). Patologic basic of disease. Philadelphia. Elsevier; 2005.

26. Middleton E, Kaswandi C, TheoharidesT.C. The effects of plants flavonoids on mammalian cells, implications for inflammation, heart disease, and cancer. The Americans Society for Pharmacology and Experimental Therapeutics. Pharmacol. 2000; 52(4):711-22.

27. Conad C, editor (penyunting). Quantification of phenolic contents and antioxidant capacity of atlantic sea cucumber, curcumaria frondosa (abstract). Beche-De-MerInformation Bulletin, Issue; 2007.

28. Suweino. Kemampuan sari mengkudu (Morinda citrifolia) dalam menangkal stress oksidatif akibat pemberian $\mathrm{CCl} 4$ pada tikus. Prosiding Seminar Nasional dan Pra Kongres PBBMI pada 2 Oktober 2004 di Yogyakarta. 2004.

29. Buckberry LD, Blagbrough IS, Shaw PN. Cysteine conjugatetoxicity in a human cell line: correlation with C-S lyase activity in human hepatic tissue. Hum exp Toxicol. 1993.

30. Adam F, Mochamad, Prijanti R, Ani, Sadikin M. Pengaruh pemberian ekstrak biji jengkol (archidendron pauciflorum) pada aktivitas spesifik katalase jaringan hati tikus yang diintoksikasi karbon tetraklorida. Jakarta: Departemen Biokimia dan Biologi Molekuler Fakultas Kedokteran Universitas Indonesia; 2013. 